\title{
Equilibrium
}

Quarterly Journal of Economics and Economic Policy

VOLUME 7 ISSUE 4, 2012

ISSN 1689-765X

\author{
Magdalena Raftowicz-Filipkiewicz ${ }^{*}$ \\ Wrocław University of Environmental \\ and Life Sciences, Poland
}

\section{Nation Branding as an Economic Challenge FOR THE Countries OF THE MidDle AND EAST EuROPE ON THE EXAMPLE OF ESTONIA}

\section{JEL Classification Codes: F60, F68}

Keywords: national branding, macro-competitiveness, Estonia

\begin{abstract}
This paper presents the topic of nation branding, which is considered as a complementary factor of the traditional economic policy implemented in a given country. The concept of branding aims at creating a strong national brand for improving the brands of national products, as well as the image of the country which influences the attraction of foreign direct investments and increase the export. The example of Estonia attempts to prove that the actions for national brand changed positively the image in this country, as well as the competitiveness of the economy. For this purpose the author used the ranking of national brand and international competitiveness. The author also set as a goal to recognize if the concept of nation branding can be useful for the other countries of Central and Eastern Europe, especially Poland. The conclusion of this paper is that nation branding is an economic challenge for these countries and should be implemented as soon as possible in their strategies of country's development.
\end{abstract}

(C) Copyright Nicolaus Copernicus University Press

Date of Submission: February 27, 2011; date of acceptance: January 28, 2012

* Contact: e-mail: m.raftowicz@ prawo.uni.wroc.pl, Uniwersytet Przyrodniczy we Wrocławiu, Instytut Nauk Ekonomicznych i Społecznych, pl. Grunwaldzki 24a, 50-363 Wrocław, Poland 


\section{INTRODUCTION}

The enlargement of the European Union created a profound opportunity for a dynamic and comprehensive development in Central and Eastern European countries, which was directly linked to the possibility of obtaining financial means for that purpose. However, the accession to the EU, as macroeconomic data indicate, has not solved the problem of competitive, technological or innovative disparities in comparison with western European countries. The good question at this point is then, how can such disparities be reduced?

The subject matter of this publication is nation branding, recognized as a supplementary and supportive element for marketing and public relations activities - macroeconomic policy pursued in a given country. Although branding activities relate to soft aspects of economy, in the long run they positively contribute to enhancing macro-competitiveness, which is exemplified by such countries as the United Kingdom, Germany or Sweden, which have been employing this concept in their respective development strategies for many years.

This article aims at analyzing the process of nation branding, as well as determining whether this concept may be successfully applied in Central and Eastern European countries. The author, using Estonia as the basis for her considerations, strived to demonstrate that branding related measures had a direct impact on boosting the position and reputation of this country internationally, hence contributed to increasing the country's competitiveness.

\section{NATION BRANDING CONCEPT}

Nation branding is a process which consists in a long-term building of a country's brand, its reputation and renown as well as effective management of its value, so that it can foster actions aimed at increasing the country's competitiveness. National image, as well as products and services originating from a given country, are the measurable indicators of a nation's brand. Strong brand may have, then, positive influence on the influx of foreign direct investment, increased export, or tourism development which is presented in the diagram 1. 
Diagram 1. Nation brand functioning process

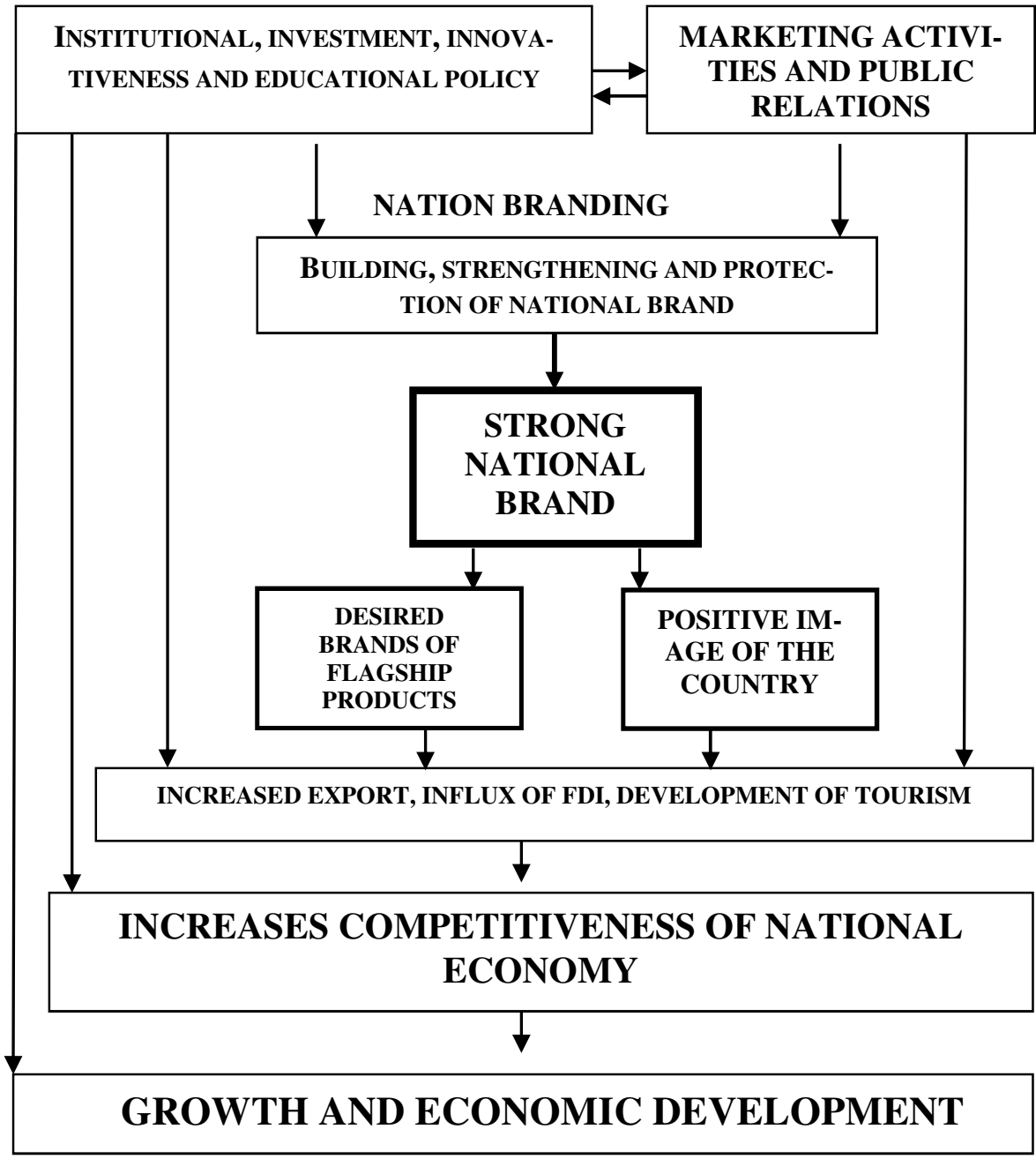

Source: own work.

As diagram 1 illustrates, the combination of hard and soft elements of economic policy which supplement and complement each other, reflects the twofold nature of the nation branding concept. On the one hand, it puts emphasis on the PR and marketing aspects, on the other it refers to macroeconomic aspects which necessitate supporting relevant activities by means of an adequate national economic policy: institutional, investment, innovativeness or educational policy. The pursued policy should be compliant with the newest trends observed in the contemporary theoretical and practical econo- 
my, i.e. it should lay special emphasis on the development of knowledge, innovations or creativity based economy. All these measures have something in common, that is they aim at increasing competitiveness regardless of whether soft or hard economic instruments are employed.

\section{SOFT ASPECT OF NATION BRANDING}

In line with the concept of nation branding - a country which aspires to become an influential partner in political and economic relations on international level and strives to enjoy respect of other countries should care about its image as well as products and services it offers.

As numerous studies indicate, a country's image plays an important role in the country's international development. I.D. Nebenzahl and E.D. Jaffe (1996, pp. 5-22) argue that effective management of country's image leads to the development of competitive advantage which is substantiated by economic indicators of countries which have recently undertaken measures to boost their national reputation.

Also studies on the dependency between country's reputation and the perception of products originating from this country, which were first carried out at the end of 1960's by R. Schooler and A. Wildt (1968, pp. 78-81), show that a positive image of a country stimulated demand for products originating from that country. Currently, with respect to most consumer goods, country of origin belongs to the first three factors determining the purchase (Daszkiewicz, Waniowski 2006, p. 540).

J. Altkorn (1999, p. 40) even recognizes that "the impact of country's image on the image of products is a consequence of civilization, cultural and economic achievements", which testifies to the great economic strength of this phenomenon.

The country of origin effect is directly linked to the halo effect. The concept, transplanted from psychological theory to economy by M.C. Han (1989, pp. 222-229), assumes that when a consumer does not have information on a product originating from a given country or this information is limited he or she will draw conclusions on the quality of this product on the basis of his own or heard opinion about the country from which the product comes. The halo effect process projects the country's image on the attitude towards a product brand originating from this country, which is linked with the tendency to evaluate this brand by means of distinctive, often stereotypical traits of a country.

Therefore, in countries enjoying good reputation a frequently applied marketing ploy consists in deliberately highlighting information about the country of origin, which boosts sales of products and services. This may be 
exemplified by such advertising slogans as: Spanish temperament, German precision, Italian style, French finesse, etc.

However, in case of Central and Eastern European countries, national reputation brings no benefits to producers. The main problem lies in their past, as even if those countries develop dynamically, they are viewed through the prism of recent history and are burdened with the nickname: post-communist, which is mostly identified with low quality of goods and services, low production efficiency and corruption. Negative image which they inherited after the legacy of centrally planned economy may act as an effective barrier for entering the European salons even though in some areas of economy such countries are doing better than their western neighbors. Another problem of Central and Eastern European countries is their anonymity on international markets, which only facilitates the spread of negative stereotypes. It turns out that the image of these countries is assessed in a more negative light than in reality (Olins 2004, p. 2).

However, research by G. Paquet (1999, p. 10) focusing on country's image in the eyes of foreigners demonstrated that the perception of a country's image is primarily dependent on the level of knowledge that a recipient has and acquires about a given country, which is presented in the Table 1.

Table 1. Level of knowledge concerning a given country and image topology

\begin{tabular}{|c|l|l|}
\hline \multicolumn{2}{|c|}{ Level of knowledge concerning a given country } & \multicolumn{1}{c|}{ Image topology } \\
\hline High & $\begin{array}{l}\text { The recipient is in constant contact with } \\
\text { different sources of information (e.g. with } \\
\text { opinion makers, ambassadors, journalists, } \\
\text { businessmen etc.); }\end{array}$ & $\begin{array}{l}\text { The image has a consistent and } \\
\text { comprehensive structure it is } \\
\text { constructed on the basis of } \\
\text { associations, symbols and } \\
\text { meanings; }\end{array}$ \\
\hline Medium & $\begin{array}{l}\text { The recipient has only general infor- } \\
\text { mation regarding a given country. } \\
\text { The image is rather a result of collective } \\
\text { opinions. The recipient can identify the } \\
\text { differences between characteristic fea- } \\
\text { tures of a given country. These features } \\
\text { are evaluated in a positive or negative } \\
\text { way, this allows the recipient to create his } \\
\text { own image on the basis of general infor- } \\
\text { mation available to him; }\end{array}$ & $\begin{array}{l}\text { The image is a sum of opinions } \\
\text { on a given subject and percep- } \\
\text { tion of characteristic features of } \\
\text { a given country. It constitutes a } \\
\text { subjective attitude to a given } \\
\text { country; }\end{array}$ \\
\hline Low & $\begin{array}{l}\text { The recipient has a minimal, general } \\
\text { knowledge of a given country. He can not } \\
\text { distinguish the country's features, this } \\
\text { image is liable to changes; }\end{array}$ & $\begin{array}{l}\text { The image is perceived as a } \\
\text { general perception } \\
\text { of the recipient. He is imprecise } \\
\text { and frequently changeable; }\end{array}$ \\
\hline
\end{tabular}

Source: own work, on the basis of G. Paquet (1999, p. 10). 
Table 1. shows that the higher the level of available information concerning a given country the more stable and lucid it is. In the case when the recipient does not have such information or if it is imprecise, then the perception of the image is superfluous and frequently negative. Therefore, the countries which want to enhance their image should first of all focus on a clear and lucid issuing of information regarding the country. Moreover, they should focus on promoting the values of the country, using the key tool of nation branding i.e. the system of visual identification of the country. This system has the goal to create and attractive leading idea behind the nation's brand and a clear and identifiable logo.

However, not every catch phrase turns out to work in practice. A frequent error in the nation branding process is an all-to-superfluous treatment of the main guiding principle, the evidence of which is the existence of almost identical promotional catch phrases in Central and Eastern European countries. Hungary is promoted by the catch phrase "The Essence of Europe", The Czech Republic - "In the heart of Europe", Lithuania - "The center of Europe", Slovenia - "Green corner of Europe", while Slovakia promotes itself as "Small country with a big heart". Poland's catch phrase "Creative tension" also seems rather bland. Estonia did, however present an interesting idea, it came up with the phrase "Positively transforming".

However, the creation of a nation's brand and logo is not a solution to all economic problems of a given country. If a brand is changed or only built superfluously, is not supported by deep changes and not trusted in the country, it has no chances to survive and be successful.

A positive example of a complex change of the country's image is Estonia, which has introduced a coherent long-term image building campaign proceeded with marketing research. The outcome was preparing their own national logo, which accentuated the geographical location of the country and is, at present, used in all promotional campaigns together with the phrase positively transforming (www.visitestonia.com).

The program of nation branding in Estonia was to reveal to the world that Estonia is a culturally rich country, open to new possibilities and pursuing the path of innovativeness and creativity. Tourist and natural values of the country were also promoted. A specific budget was allocated to the program, which included 660 thousand euro devoted to create the concept and strategy of branding Estonia, and 200 thousand euro for launching the program of nation branding connected to the Eurovision song contest in 2002 which became an element promoting Estonia in Europe (Dinnie 2008, p. 234).

The actions undertaken in 2001 towards changing the image of Estonia are slowly having the desired effects. In the ranking of national brands, according to the Anholt-GfK Roper Nation Brand Index methodology (2008; 2009), Estonia moved over the period between 2008 and 2009 from the 
place 44 to 42 , and it is assumed that in the coming years the situation will improve. A similar positive change was presented by the Country Brand Index $(2009 ; 2010)$, which in 2009 placed Estonia on the $90^{\text {th }}$ and in 2010 on the $89^{\text {th }}$ place.

These slow changes may discourage governments to carry out activities aimed at nation branding. However, as demonstrated by the example of Estonia, it has been shown that a brand can be recreated, but it is a long and time consuming process based on persistent activities and costly investments.

\section{INDIRECT EFFECT OF NATION BRANDING ON THE ECONOMY}

Nation Branding may also affect the economy directly through actions aimed at increasing export, developing tourism or influx of direct foreign investment, which could bring new technologies to the country, develop human potential, increase the attractiveness of investment etc. This, however requires an active support of the country in order to create a helpful environment (both in the macro and micro scale), which would eliminate economic barriers and would contribute to the improvement of macro-economic competitiveness. One of such actions is to prepare appropriate strategy of the country's development, which would include macroeconomic provisions of nation branding i.e. emergence of national specializations so as to promote: products, services, investment sites etc.

Advisory-institutional support on the part of the state also plays an important role. It is just as important that exporters can benefit from such privileges as insurance from political and trade risk, tax reliefs on export and trade in technology, export supporting loans and subsidies quicker amortization of manufacturing equipment, reserve funds in case of losses and funds covering costs of foreign marketing including financial aid supporting exhibitors and participation in trade fairs.

The example of Estonia reveals that in a short period of time a state can become a leader among new EU member states. The causes of such a state of affairs might include a number of issues. Firstly, it results from the assumed economic model, which applies to the concept of nation branding.

This model assumed first of all a decisive opening of the economy to foreign competition and obtaining foreign direct investment. The pressure to develop human capital was also an important element, just as the pressure to invest in the country's infrastructure and the combination of low wages and attractive tax environment (Ketels 2006, p. 8). 
At present, it is exactly the foreign investments in Estonia that constitutes the main source of financing economic activity. It is also conducive to technology transfer, introducing modern methods of management and promoting foreign trade. Investments, in turn, contributed to the development of innovativeness of the state and are, at present - in contrast to other countries - the powerhouse of Estonian developing economy. Estonia, also has an admirable low level of public debt, highly effective market and flexible wages. The relevance of trade is increasing, while in 2004 exports were exceeding imports. Moreover, in comparison to other Baltic states, Estonian exports are not dominated by labor demanding raw materials, and the share of highly processed goods, machines, electronic, electro-technical and transport equipment.

The confidence regarding its own strengths based on a highly educated society made modern Estonia one of the most developed and competitive states of Central and Eastern Europe, which is confirmed by the country's position in competitiveness rankings (Table 2) and the introduction of Euro in 2011. The country has been affected by the outcomes of the economic crisis of the recent years, which contributed in a major way to the rapid decrease of GDP by $15 \%$ in the $3^{\text {rd }}$ quarter of 2011 . Nevertheless, it is estimated that in 2011 the growth will amount to $4,4 \%$ which is the best indicator among the 3 Baltic states (Statistics Estonia, 2010).

Table 2. Competitiveness ranking in the selected Central and Eastern European states according to WEF in 2005, 2007 and 2010

\begin{tabular}{|c|l|l|l|}
\hline Country & $\mathbf{2 0 0 5}$ & $\mathbf{2 0 0 7}$ & $\mathbf{2 0 1 0}$ \\
\hline Estonia & 26 & 27 & 33 \\
\hline Czech Republic & 29 & 33 & 36 \\
\hline Poland & 43 & 51 & 39 \\
\hline Slovenia & 30 & 39 & 45 \\
\hline Hungary & 35 & 47 & 52 \\
\hline
\end{tabular}

Source: World Economic Forum (2005; 2007; 2010).

Without doubt, it is difficult to specify exactly to what extent those changes were caused by the nation branding program. However, on the basis of the analysis, it is possible to state that the actions aimed at nation branding, which were supposed to create new attractive image, attract foreign investment and strengthening exports, positively influence the improvement of the economic situation of the country and, in the times of crisis, effectively helped to offset its effects. 


\section{NATION BRANDING IN POLAND}

In the perspective of the coming years, the Polish economy will have to face certain serious macroeconomic and institutional challenges. These might be the foundation for improving, maintaining or weakening of our country's competitiveness in the global economy. Unfortunately, as perceived by A. and S. Stysiowie (2004, pp. 65-66), Poland is witnessing a growing division between economic entities and the institutions of power and administration, which is constantly getting deeper. Numerous symptoms of a still not fully functional role of the state in the market economy confirm that improving macro-competitiveness without a comprehensive national strategy seems impossible. Moreover, further progress in employing fully developed marketing and public relations tools (both by businesses and the state) without implementing such national strategy on every level (i.e. central, regional and local bodies) its effect will be limited. This proves that the functioning of the country's economy in the age of progressing globalization requires putting emphasis on the problem of coherent development of national macro-policy aligned with the trends of global economy that take into consideration soft factors and modern determinants of the country's development. In practice, this means pursuing the path set out by nation branding.

Unfortunately in Poland, actions towards nation branding still bring little results, although they were initiated over ten years ago. This is a consequence of lack of support for this concept on the side of subsequent governments and the lack of vision of the country's development.

\section{CONCLUSIONS}

Summarizing these analyses, we might arrive at the conclusion that actions taken towards nation branding may constitute a relevant element of the country's economic policy, which is supposed to create a strong and attractive national brand, positively influence the country's image, influx of direct foreign investment, strengthening exports or the development of tourism. Viewed from such perspective nation branding is considered as a complementary factor to other hard factors driving economic growth, while the programs of nation branding support the country's traditional economic development policy with their marketing and public relation tools.

The example of Estonia has shown that the use of the concept of nation branding in the country's economic development policy is slowly contributing to the change of the country's image and translates positively on the entire sphere of economy. Therefore, a conclusion might be drawn that this 
concept is effective - although expensive, while the effects of all the actions taken will only be visible after many years.

The discussed concept can therefore constitute a challenge also for other countries of the Central and Eastern Europe, encouraging them to effectively break away from the past and to create its image anew. In the longer perspective, nation branding can also help to eliminate economic disproportions between eastern and western Europe. This should also be the path taken by Poland, since its branding potential has not been fully employed thus far, and a coherent vision of how to make a name for itself on global markets seems to be lacking.

\section{LITERATURE}

Altkorn J. (1999), Strategia marki, PWE, Warszawa.

Anholt-GfK Roper Nation Brand Index, www.image-schweiz.ch/.../Switzerland_ 2009_NBI_Report_08-31-2009.pdf.

Anholt-GfK Roper Nation Brand Index, www.nation-branding.info/2008/10/01/ anholts-nation-brand-index-2008-released /2008-9.

Country Brand Index, www.futurebrand.com/wp-content/.../CBI_BBC_2010_exec summary.pdf.

Daszkiewicz M., Waniowski P. (2006), Marka narodowa w kreowaniu wizerunku produktów, [in:] J. Kall, B. Sojkin (ed.), Zarzadzanie produktem - wyzwania przyszłości, AE w Poznaniu, Poznań.

Dinnie K. (2008), Nation branding, concepts, issues, practice, Elsevier, Oxford.

Han M.C. (1989), Country Image: Halo or Summary Construct, "Journal of Marketing Research", No. 5.

Ketels Ch. (2006), The Baltic Tigers - An end in sight for the growth story?, Baltic Rim Economies, "Bimonthly Review", No. 31/10.

Nebenzahl I. D., Jaffe E. D., (1996), Measuring the joint effect of brand and country image in consumer evaluation of global products, "International Marketing Review", Vol. 13, Issue 4.

Olins W. (2004), Wally Olins o marce, Instytut Marki Polskiej, Warszawa.

Paquet G. (1999) Approche conceptuelle de l'image d'un pays, Raport de l'image de la Belgique, Bruxelles.

Schooler R., Wildt A. (1968), Elasticity of Product Bias, "Journal of Marketing Research", No. 5.

Statistics Estonia, www.stat.ee (10.03.2011).

Styś A., Styś S. (2004), Marketing jako orientacja kierownicza, [in:] L. Garbarski (ed.), Kontrowersje wokót marketingu w Polsce, tożsamość, etyka, przyszłość, Wyższa Szkoła Przedsiębiorczości i Zarządzania im. Leona Koźmińskiego w Warszawie, Warszawa. 
World Economic Forum, Global Competitiveness Report 2005-2006, www.weforum.org/site/homepublic.nsf/Content/Growth+Competitiveness+Inde $\mathrm{x}+$ rankings+2006+and+2005+comparisons (10.03.2011).

World Economic Forum, Global Competitiveness Report 2007-2008, www.memb ers.weforum.org/pdf/Global_Competitiveness_Reports/Reports/gcr_2007/gcr20 07_rankings.pdf (10.03.2011).

World Economic Forum, Global Competitiveness Report 2010-2011, www3.wefo rum.org/docs/WEF_GlobalCompetitivenessReport_2010-11.pdf, (10.03.2011). www.visitestonia.com (10.03.2011). 

